\title{
報文
}

色材，66 (7)，405-410 (1993)

\section{官能基の少ないカーボンブラックへのグラフト反応（第 $\mathbf{9}$ 報）}

\author{
カーボンブラック表面の縮合芳香族環に対するポリマーの \\ フリーデルークラフッ反応
}

坪川紀 夫*・村松美紀子*・藤木一浩**

要旨

官能基の少ないカーボンブラック表面へのポリマーの高グラフト化を目的に, 粒子表面の縮合芳香族環へのポ リマーのフリーデルークラフッ反応について検討した。塩化アルミニウム触媒下, カーボンブラックにアシルク ロリド基末端のポリプロピレンオキシド（PPG-COC1）を60 で反応させると，カーボンブラック表面の縮合 芳香族環へのフリーデルークラフッ反応が進行し，粒子表面へ PPG が効率よくグラフトすることが分かった。 さらに, PPG-COC1 の分子量が大きいほど, グラフト率の大きなるのが得られるが, 粒子表面へグラフトするポ リマー鎖の数はかえって低下することも分かった。さらに，グラフト反応に及ぼす反応温度の影響や PPG がグ ラフトしたカーボンブラックの有機溶媒中への分散安定性についても検討した。

\section{1. 緒言}

すでに筆者らは, カーボンブラック表面のカルボキシ ル基やフェノール性水酸基を足場とする各種ポリマーの グラフト反応について 報告してきだ,2)。例えば, カー ボンブラック表面のカルボキシル基は, アゾ基卓やペル オキシェステル基 ${ }^{4)}$, カリウムカルボン酸塩基 ${ }^{5)}$, さらに はアシリウムパークロレート基到に変換でき，これらの 官能基を導入したカーボンブラックを用いると，様々な モノマーのラジカル，アニオン，さらにはカチオングラ フト重合が可能である。

しかしながら，ファーネスブラックやアセチレンブラ ックなどの表面官能基をほとんど持たないカーボンブラ ック表面へのポリマーの高グラフト化は, グラフト反応 の足場がないため, 特別の場合を除いて困難で㐫った。

前報では, カーボンブラック表面の縮合芳香族環が強 力なラジカル捕捉性)を持つことに着目し，アゾポリマ ー8)やペルオキシポリマー9),10)の熱分解で生成するポリ マーラジカルを粒子表面の縮合芳香族環で捕捉すること

平成 5.1 .19 受理

* 新潟大学工学部化学システム工学科 新潟市五十嵐二の町 8050 (宁950-21)

** 現 上越教育大学

$\dagger$ 前報：色材協会誌，66，280（1993）
により，官能基の少ないカーボンブラック表面へも様々 なポリマーがグラフトできることを報告した。

また，カーボンブラック表面の縮合芳香族環は，様从 な求電子試薬と反応するので11), 官能基の少ないカーボ ンブラック表面への官能基導入反応に利用できることも 報告した。

ところで，芳香族化合物へのハロゲン化アルキルやハ ロゲン化アシル化合物のフリーデルークラフッ反応は古 くから知られている。ぬた, カーボンブラック表面への ハロゲン化アルキルのフリーデルークラフッ反応を行ら と，粒子表面へアルキル基が導入できることが報告され ている(2)。

そこで，本研究では，官能基の少ないカーボンブラッ クへのポリマーの高グラフト化を目的に, 粒子表面の縮 合芳香族環へのアシルクロリド基末端ポリマーのフリー デルークラフッ反応（(1) 式）を利用した, 表面グラフ ト反応について検討した。

\section{2. 実験}

\section{1 カーボンブラックおよびグラファイト微粉}

実験に使用したカーボンブラックは, ファーネスブラ ックの Philblack O と Philblack I (Philips Petroleum Co.), チャンネルブラックの Neospectra II (Colum- 


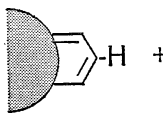

$\mathrm{CB}$

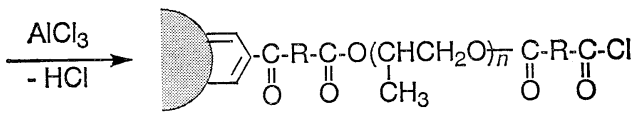

R: $\quad-\left(\mathrm{CH}_{2}\right)_{2-} \quad$ PPG-COCl(S) $-\left(\mathrm{CH}_{2}\right)_{4^{-}} \quad$ PPG-COCl$(\mathrm{A})$ त) PPG-COCI(P)

bian Carbon Co.), 括よびアセチレンブラックの電化ブ ラック（電気化学工業（株））であり，使用前に $110^{\circ} \mathrm{C}$ で十分真空㲦燥させた。

一方，グラファイト微粉は，日立粉末治金（株）から 提供を受けた GP-78を, $110^{\circ} \mathrm{C}$ で十分真空乾燥させて から使用した。

これらのカーボンブラック拉よびグラファイト微粉の 性状を表-1 に示した。

\section{2 試 薬}

末端ジオール型のポリプロピレンオキシド (PPG) は 和光純薬工業（株）の分子量が 1000，2000，および 3000 のものを $70^{\circ} \mathrm{C}$ で真空乾燥させてから使用した。

無水塩化アルミニウム拉よび無水塩化亜鉛は, 関東化 学（株）の特級品をとのまま使用した。

コハク酸ジクロリド (SC), アジピン酸ジクロリド ( $\mathrm{AC})$ ，就よびフタル酸ジクロリド (PC) は，東京化成 工業（株）の特級品をそのまま使用した。

1, 4-ジオキサンは金属ナトリウム上で還流した後, 蒸 留により精製してから使用した。

\section{3 アシルクロリド基末端ポリマー(PPG-COCl)の} 合成

三つロフラスコに $0.01 \mathrm{~mol}$ のP PG を加え, これに 0. $02 \mathrm{~mol}$ のカルボン酸ジクロライド ( $\mathrm{SC}, \mathrm{AC}$ ，または

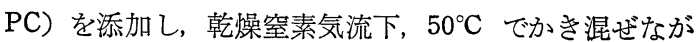
ら 3 時間反応させた ${ }^{13)}$ 。反応後, 副生した塩化水素を減 圧下で十分に除去した。 $\mathrm{SC}, \mathrm{AC}$ ，および PCを用いて 合成したアシルクロリド基末端 PPG を, それぞれ PPG-COCl (S), PPG-COCl (A), おょび PPG-COCl (P) と略記する。

\section{4 カーボンブラックと PPG-COCl とのグラフト 反応}

$100 \mathrm{~cm}^{3}$ のフラスコにカーボンブラック $0.30 \mathrm{~g}$ と所 定量 $(2.5 \mathrm{mmol})$ の PPG-COCl を科り取り,ついで無 水塩化アルミニウム $0.66 \mathrm{~g}(5.0 \mathrm{mmol})$ とジオキサン $10.0 \mathrm{~cm}^{3}$ とを加光, 乾燥窒素雾囲気下, $60^{\circ} \mathrm{C}$ でかき混 ぜながら反応させた。反応後, 生成物をメタノール中に 分散させて，遠心分離を行いポリマーグラフトカーボン ブラックを完全に沈降させた。次いで，これをメタノー ルを溶媒に用いてソックスレー抽出を行い，未反応のポ リマーを完全に除去した。

グラフト率は，（2）式から求めた。

$$
\text { グラフト率 }(\%)=\frac{\mathrm{A}}{\mathrm{B}} \times 100
$$

$\mathrm{A} ：$ グラフトしたポリマーの質量 $(\mathrm{g})$

B：用いたカーボンブラックの質量 $(\mathrm{g})$

なお,グラフトしたポリマーの質量は, 反応後のカー ボンブラックの質量増加から求めた。

\section{$2.5 \mathrm{PPG}$ がグラフトしたカーボンブラックの分散安} 定性

PPG をグラフトしたカーボンブラックの分散安定性 は, 試料をテトラヒドロフラン中へ分散させた後, 室温 に所定時間静置後, 所定量の分散液を取り出し, 分散媒 中に分散しているカーボンブラックの量から評価した。 実験方法の詳細は，前報8で述べた。

\section{3. 結果と考察}

\section{1 PPG-COCl の同定}

アシルクロリド基末端のポリマーは，前報 ${ }^{131}$ 飞従い分

Table 1 Properties of carbon black and graphite powder used

\begin{tabular}{|c|c|c|c|c|c|}
\hline Carbon black & $\begin{array}{l}\text { BET surface } \\
\text { area }\left(\mathrm{m}^{2} / \mathrm{g}\right)\end{array}$ & $\begin{array}{c}\text { Particle } \\
\text { size (nm) }\end{array}$ & $\underset{(\mathrm{mmol} / \mathrm{g})}{\mathrm{OH}}$ & $\underset{(\mathrm{mmol} / \mathrm{g})}{\mathrm{COOH}}$ & $\begin{array}{c}\mathrm{C}=\mathrm{O} \\
(\mathrm{mmol} / \mathrm{g})\end{array}$ \\
\hline Philblack $\mathrm{O}^{\mathrm{a}}$ & 79. 6 & 29.4 & 0.02 & 0 & 0.18 \\
\hline Philblack I ${ }^{\mathrm{a}}$ & 116.8 & 28.6 & 0.05 & 0 & 0.23 \\
\hline Denkablack ${ }^{\mathrm{b}}$ & 65 & 40 & 0.02 & 0 & 0.01 \\
\hline Neospectra $I^{c}$ & 906 & 13 & 0.24 & 0.40 & 0.92 \\
\hline GP-78d & - & 4000 & 0.01 & 0 & 0.08 \\
\hline
\end{tabular}

${ }^{\mathrm{a}}$ Furnace black. ${ }^{\mathrm{b}}$ Acetylene black. ${ }^{\mathbf{c}}$ Channel black. ${ }^{\mathrm{d}}$ Graphite powder. 


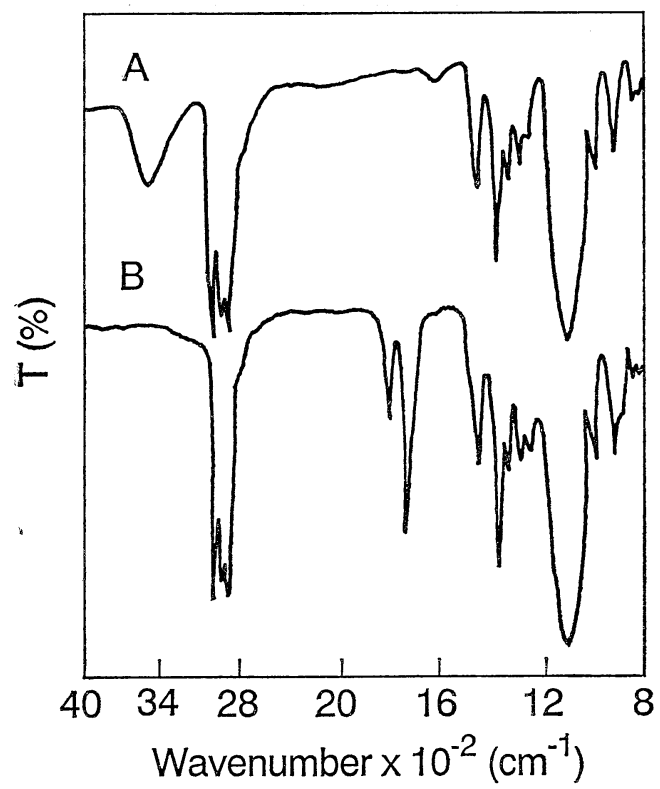

Fig. 1 Infrared spectra of (A) PPG and (B) phthaloyl chloride-capped PPG (PPG$\mathrm{COCl}$ (P 2))

子量の異なる ( $\overline{\mathrm{Mn}}=1000,2000$, および 3000) PPG と カルボン酸ジクロリドとの反応により合成した。

図-1 には，PPG $\overline{(\overline{M n}}=2000)$ と $\mathrm{PC}$ との反応で得ら れた PPG-COCl (P 2) の IR スペクトルを PPG のそ れと比較して示した。PPG-COCl (P 2) のIR スペクト ルには $3500 \mathrm{~cm}^{-1}$ の水酸基に基づく吸収が完全に消失 し，新たに $1800 \mathrm{~cm}^{-1}$ にアシルクロリド基，さらに 1740 $\mathrm{cm}^{-1}$ にエステル結合の特性吸収が認められる。

また，PPG-COCl(S)，PPG-COCl(A)，および PPG$\mathrm{COCl}(\mathrm{P})$ の数平均分子量を蒸気圧浸透 (VPO) 法で求 めた結果を表-2 に示した。な挔，PPG-COCl(S 1), $\mathrm{PPG}-\mathrm{COCl}(\mathrm{S} 2)$, および PPG-COCl(S 3) は分子量が,

Table 2 Molecular weight of PPG-COCl determined by VPO

\begin{tabular}{c|c|c|c|c}
\hline & & \multicolumn{3}{|c}{$\overline{\mathrm{Mn}} \times 10^{-3}$} \\
\cline { 3 - 5 } PPG-COCl & $\begin{array}{c}\text { Acid } \\
\text { chloride }\end{array}$ & $\begin{array}{c}\text { PPG } \\
\text { used }\end{array}$ & \multicolumn{2}{|c}{$\begin{array}{c}\text { COCl-capped } \\
\text { PPG }\end{array}$} \\
\cline { 3 - 5 } & & Calcd. & Obsd. \\
\hline PPG-COCl (S 1) & SC & 1.0 & 1.24 & 1.3 \\
PPG-COCl (S 2) & SC & 2.0 & 2.24 & 2.4 \\
PPG-COCl (S 3) & SC & 3.0 & 3.24 & 3.2 \\
PPG-COCl (A 2) & AC & 2.0 & 2.29 & 2.4 \\
PPG-COCl (P 2) & PC & 2.0 & 2.33 & 2.3 \\
\hline
\end{tabular}

それぞれ 1000，2000，拈よび 3000 のPPG から合成し たものであることを示す。PPG-COCl の分子量は，それ ぞれの理論分子量に近く, PPG の鎖長延長反応はほ んぞ起こっていないものと考觉られる。

以上の結果から，両末端がアシルクロリド基で置換さ れた PPG が生成しているものと考光られる。

\section{2 カーボンブラック表面への PPG-COCl のフリ ーデルークラフツ反応}

すでに筆者らは，アルカリ触媒下，カーボンブラック にホルムアルデヒドを反応させると, 粒子表面の縮合芳 香族環へのホルムアルデヒドの求電子置換反応が起こ り，粒子表面へメチロール基が導入できることを報告し た ${ }^{11)}$ そこてで, 本研究では，カーボンブラック表面縮合 芳香族環への PPG-COCl の求電子置換反応（フリーデ ルークラフッ反応）による粒子表面への PPG のグラフ ト反応 ((1) 式) について検討した。

表-3 には, 各種の条件下で, PPG-COCl(S 2) とカー ボンブラックとの反応を行ったときの結果を示した。カ ーボンブラックに PPG，㐫いは PPG-COCl(S 2) を 無触媒下で反応させたとさ（Run 1,3）や塩化アルミ= ウムの存在下で PPG を反応させたとき（Run 2)，粒子 表面に残存する $\mathrm{PPG}$ の量は 4.0～5.1\% にすぎなかっ た。なお，これらの值は，PPG-COCl(S 2) のアシルク ロリド基をブロックしたポリマーのカーボンブラック表 面への吸着率 $(5.0 \%)$ とほぼ等しいので，これらの系で は，グラフト反応は全く進行しないものと考えられる。 これに対して，塩化アルミニウムや塩化巠鉛などのルイ ス酸触媒下では (Run 4, 5), PPG-COCl(S 2) のグラフ ト反応が進行することが分かった。

なお，このような系で得られるカーボンブラックは， PPG の良溶媒中へ完全に分散し，ゲルの生成は全く認 められなかった。したがって，カーボンブラック表面の グラフト鎖末端のアシルクロリド基は，他の粒子表面と 反応しないこと（( 3 ) 式）を示唆している。これは, カ

Table 3 Reaction of PPG-COCl (S 2) with carbon black under several conditions ${ }^{\mathrm{a}}$

\begin{tabular}{c|l|c|c}
\hline Run & \multicolumn{1}{|c|}{ Polymer } & Catalyst & Grafting (\%) \\
\hline 1 & PPG & - & 4.7 \\
2 & PPG & $\mathrm{AlCl}_{3}$ & 5.1 \\
3 & PPG-COCl (S 2) & - & 4.0 \\
4 & FPG-COCl (S 2) & $\mathrm{AlCl}_{3}$ & 32.1 \\
5 & PPG-COCl (S 2) & $\mathrm{ZnCl}_{2}$ & 22.8 \\
\hline
\end{tabular}

a Philblack O, $0.30 \mathrm{~g}$; catalyst, $5.0 \mathrm{mmol}$; polymer, $2.5 \mathrm{mmol}$; dioxane, $10.0 \mathrm{~cm}^{3}, 60^{\circ} \mathrm{C}$; $24 \mathrm{~h}$. 

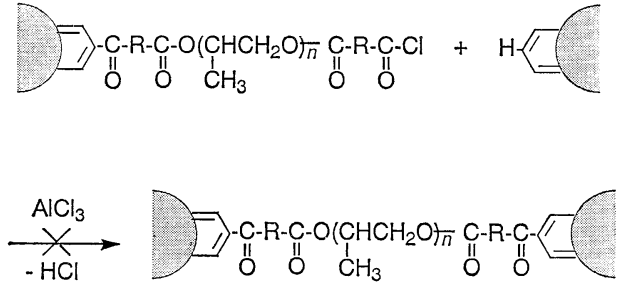

Table 4 Grafting of PPG by Friedel-Crafts reaction of several $\mathrm{PPG}-\mathrm{COCl}$ with carbon black ${ }^{a}$

\begin{tabular}{c|c|c}
\hline PPG-COCl & $\overline{\mathrm{Mn}} \times 10^{-3}$ & Grafting (\%) \\
\hline PPG-COCl (S 2) & 2.4 & 32.1 \\
PPG-COCl (A 2) & 2.4 & 20.0 \\
PPG-COCl (P 2) & 2.3 & 18.5 \\
\hline
\end{tabular}

a Philblack O, $0.30 \mathrm{~g} ; \mathrm{AlCl}_{3}, 5.0 \mathrm{mmol}$; polymer, $2.5 \mathrm{mmol}$; dioxane, $10.0 \mathrm{~cm}^{3} ; 60^{\circ} \mathrm{C}$; $24 \mathrm{~h}$.

ーボンブラックに対して大過剰の PPG-COCl を使用し ているためと考えられる。

表-4には，塩化アルミニウム触媒下で，カーボンブラ ックへの PPG-COCl(A 2), および PPG-COCl(P 2) の フリーデルークラフッ反応を行ったときの結果を PPG$\mathrm{COCl}(\mathrm{S} 2)$ の場合と比較して示した。これから, カーボ ンブラック表面に対する PPG-COCl の反応性は, PPG$\mathrm{COCl}(\mathrm{S})>\mathrm{PPG}-\mathrm{COCl}(\mathrm{A})>\mathrm{PPG}-\mathrm{COCl}(\mathrm{P})$ の順に低 下することが分かった。これは，この順で末端アシリウ ムイオンの求電子反応性が低下するためと考觉られる。

\section{3 各種カーボンブラックおよびグラファイト微粉} への PPG-COCl のグラフト反応

表-5 には，塩化アルミニウム触媒下， PPG-COCl(S 2) と各種カーボンブラックおよびグラファイト微粉と のグラフト反応を行ったときの結果を示した。これか

Table 5 Grafting onto several carbon blacks and graphite powder by Friedel-Crafts reaction with $\mathrm{PPG}-\mathrm{COCl}(\mathrm{S} 2)^{\mathrm{a}}$

\begin{tabular}{l|c}
\hline Carbon black & Grafting (\%) \\
\hline Philblack O & 38.7 \\
Philblack I & 34.7 \\
Denkablack & 28.3 \\
Neospectra II & 44.9 \\
GP-78 & 7.8
\end{tabular}

a Carbon black, $0.30 \mathrm{~g} ; \mathrm{AlCl}_{3}, 5.0 \mathrm{mmol}$; PPG$\mathrm{COCl}$ (S 2), $2.5 \mathrm{mmol}$; dioxane, $10.0 \mathrm{~cm}^{3} ; 60$ ${ }^{\circ} \mathrm{C} ; 48 \mathrm{~h}$.

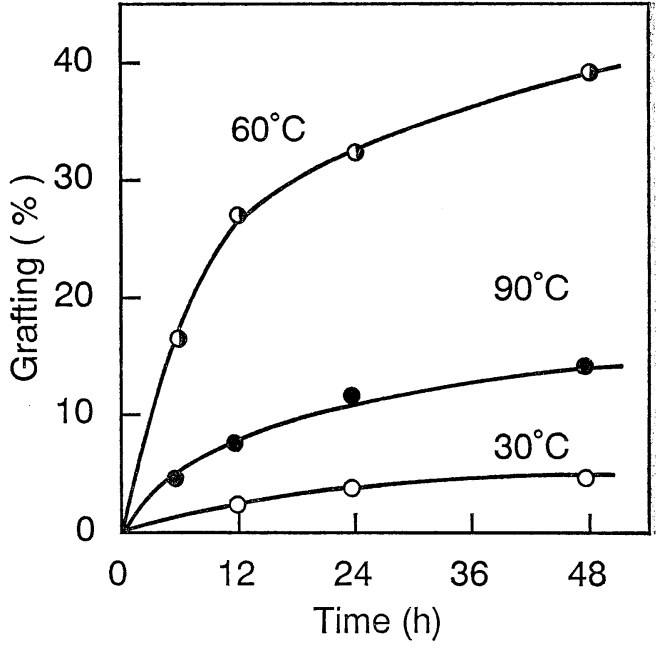

Fig. 2 Effect of temperature on the grafting of PPG onto carbon black by FriedelCrafts reaction of PPG-COCl (S2). Philblack O, $0.30 \mathrm{~g} ; \mathrm{AlCl}_{3}, 5.0 \mathrm{mmol}$; PPG$\mathrm{COCl}$ (S 2), $2.5 \mathrm{mmol}$; dioxane, $10.0 \mathrm{~cm}^{3}$

ら，フリーデルークラフッ反応を利用することにより， 官能基の少ないカーボンブラックやグラファイト微粉表 面へもポリマーがグラフトできることが明らかとなっ た。

な拉, Neospectra II 表面へのグラフト率が他のカー

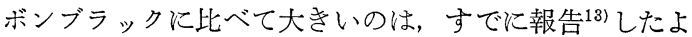
らに, 粒子表面のフェノール 性水酸基と PPG-COCl(S 2）とのエステル化反応によるグラフトも起こっている ためと考えられる。

\section{4 グラフト反応に及ぼす反応温度の影響}

図-2には, 塩化アルミニウム触媒下での, カーボンブ ラック表面への PPG-COCl(S 2) のグラフト反応に及ぼ す反応温度の影響を調べた結果を示した。これから，30 ${ }^{\circ} \mathrm{C}$ では，ほとんどグラフト反応が進行しないことが分 かった。また，反応温度が $90^{\circ} \mathrm{C}$ の系では $60^{\circ} \mathrm{C}$ の系よ りもグラフト率は，かえって低下した。これは，高温で は，グラフト鎖中や PPG-COCl(S 2) 中のエステル結合 の加水分解反応が一部起こるため，グラフト反応が抑制 されるためと考光られる。

\section{5 グラフト反応に及ほす PPG-COCl の分子量の 影響}

表-6 には, カーボンブラック表面へのグラフト反応 に及ぼす PPG-COCl(S) の分子量の影響を調べた結果 を示した。表-6 の結果は, $\mathrm{PPG}-\mathrm{COCl}(\mathrm{S})$ の分子量が 大きくなるほど，粒子表面への PPG のグラフト率は大 
Table 6 Effect of molecular weight of PPG$\mathrm{COCl}(\mathrm{S})$ on the grafting onto carbon black surface ${ }^{\text {a }}$

\begin{tabular}{c|c|c|c}
\hline PPG-COCl & $\overline{\mathrm{Mn}} \times 10^{-3}$ & $\begin{array}{c}\text { Grafting } \\
(\%)\end{array}$ & $\begin{array}{c}\text { Grafted PPG } \\
(\mathrm{mmol} / \mathrm{g})\end{array}$ \\
\hline PPG-COCl (S 1) & 1.3 & 32.1 & 0.25 \\
PPG-COCl (S 2) & 2.4 & 38.7 & 0.16 \\
PPG-COCl (S 3) & 3.2 & 41.3 & 0.13 \\
\hline
\end{tabular}

a Philblack O, $0.30 \mathrm{~g} ; \mathrm{AlCl}_{3}, 5.0 \mathrm{mmol}$; polymer, $2.5 \mathrm{mmol}$; dioxane, $10.0 \mathrm{~cm}^{3} ; 60^{\circ} \mathrm{C} ; 48 \mathrm{~h}$.

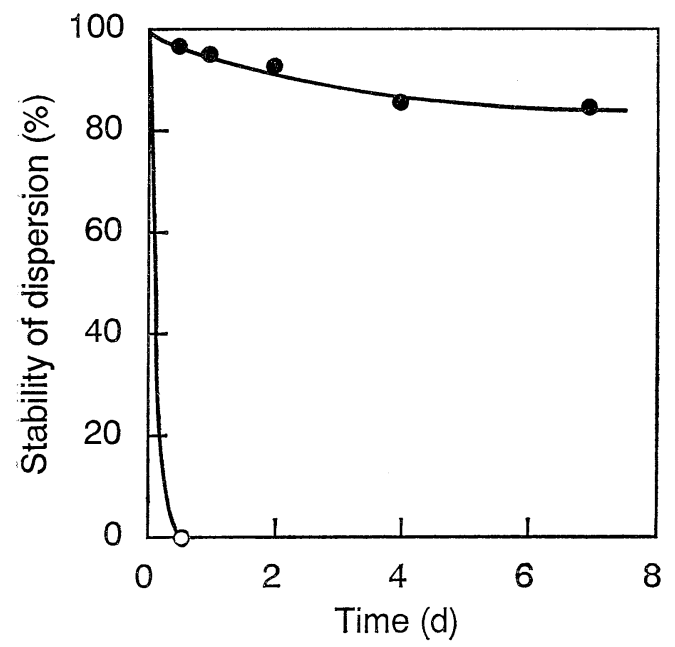

Fig. 3 Stability of PPG-COCl (S 2)-grafted carbon black dispersion in tetrahydrofuran at room temperature. ( $\bigcirc)$, untreated; (9), $\mathrm{PPG}-\mathrm{COCl}$ (S 2)-grafted (grafting= $38.7 \%)$.

きくなるが, 粒子表面へグラフトしたポリマー 鎖の 数 は, かえって低下することを示している。このような現 象は，カーボンブラック表面へ導入した反応性官能基と 官能性ポリマーとのグラフト反応に祘いても観察され る21,14。これは，ポリマーの分子量が大きくなると，ポ リマー鎖は糸鞠状となり末端基の反応性が低下すること と，グラフト鎖が粒子表面をブロックする効果が大きく なるためと考えられる。

\section{$3.6 \mathrm{PPG}$ をグラフトレたカーボンブラックの分散安} 定性

図-3 には，PPG をグラフトしたカーボンブラックの テトラヒドロフラン中への分散安定性を調べた結果を示
した。未処理のカーボンブラックは，短時間のうらに完 全に沈降してしまうのに対して，PPG をグラフトした カーボンブラックは，長期間にわたり安定に分散するこ とが分かった。これは，グラフト鎖がカーボンブラック 粒子相互の凝集を妨害するためと推察できる。

\section{4. ま め}

カーボンブラックに, 塩化アルミニウム触媒下, PPG$\mathrm{COCl}$ を反応させると，粒子表面の縮合芳香族環へのフ リーデルークラフッ反応が進行し, 粒子表面へ PPG が グラフトできることが分かった。また, PPG-COCl の分 子量が大きくなると，グラフト率は増大するが，グラフ トするポリマー鎖の数はかえって低下することも明らか となった。このような方法を用いると, 表面官能基が少 ないため, 従来の方法では高グラフト化が困難であっ た，カーボンブラック表面へも様々なポリマーがグラフ トできることが分かった。

\section{引用 文 献}

1) 坪川紀夫, 遠藤 剛: 炭素, No. 140, 322(1989).

2) N. Tsubokawa : Prog. Polym. Sci., 17, 417 (1992).

3) K. Fujiki, N. Tsubokawa, and Y. Sone : Polym. J., 22, 661 (1990).

4) N. Tsubokawa, K. Fujiki, and Y. Sone : Polym. J., 20, 213 (1988).

5) N. Tsubokawa, A. Funaki, Y. Hada, and Y. Sone : J. Polym. Sci., Polym. Chem. Ed., 20, 3297 (1982).

6) N. Tsubokawa : J. Polym. Sci., Polym. Chem. Ed., 21, 705 (1983).

7) M. Levy and M. Szwarc: J. Chem. Phys., 22, 1621 (1954).

8）坪川紀夫，梁取和人：高分子論文集， 49,865 (1992).

9）半田智史, 坪川紀夫, 押部義宏, 山本 隆: Polym. Preprints, Japan, 41, 1926 (1992).

10) N. Tsubokawa and S. Handa : '92 International Conference on Colour Materials, p. 50 (1992).

11）藤木一浩, 真柄和朗, 坪川紀夫, 曾根康夫 : 日本 ゴム協会誌, 64, 378 (1991).

12) J. W. Watson, C. E. Kendall, and R. Jervis, U. S. P., 3, 043, 708.

13) N. Tsubokawa, M. Hosoya, K. Yanadori, and Y. Sone : J. Macromol. Sci. -Chem., A 27, 445 (1990).

14) N. Tsubokawa, A. Kuroda, and Y. Sone : Polym. J., 20, 721 (1988). 


\title{
Grafting onto Carbon Black Having Few Functional Groups (9 th Report) : Friedel-Crafts Reaction of Polymers with Polycondensed Aromatic Rings of Carbon Black Surface
}

\author{
Norio Tsubokawa*, Mikiko Muramatsu* and Kazuhiro Fujiki* \\ * Department of Material and Chemical Engineering, Faculty of Engineering, Niigata \\ University, 8050, Ikarashi 2-nocho, Niigata 950-21, Japan
}

\begin{abstract}
The grafting of polymers on to carbon black by Friedel-Crafts reaction of acyl chloride-capped polymers with polycondensed aromatic rings of the surface was investigated. Acyl chloride-capped polymers (PPG-COCl) were prepared by the reaction of diol-type poly (propylene oxide) (PPG) with carboxylic acid dichloride, such as succinyl dichloride, adipoyl dichloride, and phthaloyl dichloride. It was found that by the reaction of carbon black with PPG-COCl in the presence of $\mathrm{AlCl}_{3}$ at $60^{\circ} \mathrm{C}$, PPG was successfully grafted onto carbon black surface. On the contrary, by the treatment of carbon black with PPG in the presence of $\mathrm{AlCl}_{3}$ and by the treatment with PPG-COCl in the absence of $\mathrm{AlCl}_{3}$, the grafting of PPG onto carbon black surface was rarely observed. Based on the above results, it was concluded that the grafting of PPG on to the carbon black surface proceeded by Friedel-Crafts reaction of PPG-COCl with polycondensed aromatic rings of carbon black surface. The percentage of grafting increased with increasing molecular weight of PPG-COCl, but the number of grafted PPG chain decreased. The effects of reaction temperature and catalyst on the grafting reaction were also discussed. Furthermore, PPG-grafted carbon black gave a stable colloidal dispersion in a good solovent for PPG.
\end{abstract}

Key-wrods : Carbon black, Surface grafting of polymer, Friedel-Crafts reaction, Acyl chloride-capped polymer, Dispersibility 